\title{
Rheumatoid factor activity in heroin addicts on methadone maintenance
}

\author{
HARRY SPIERA, IRWIN ORESKES, AND BARRY STIMMEL \\ From the Department of Medicine and the Clinical Research Center, Mount Sinai School of Medicine, \\ City University of New York, Fifth Avenue and 100th Street, New York, NY 10029, U.S.A.
}

It is now well known that rheumatoid factors (RF) or antigamma globulin antibodies are found in many individuals with a wide variety of diseases other than rheumatoid arthritis (Bartfeld, 1960, 1969; Oreskes and Spiera, 1966, 1967). In many of these diseases the presence of RF seems to be related to a previous or concurrent history of chronic antigenic stimulation. Examples of this include cases of subacute bacterial endocarditis (Williams and Kunkel, 1962) and tuberculosis (Singer, Plotz, Peralta, and Lyons, 1962), as well as diabetics on long-term insulin therapy (Oreskes and Spiera, 1973). Similarly, RF is present in patients who have received multiple transfusions (Vierucci, 1965) or vaccinations (Aho, Konttinen, Rajasalmi, and Wager, 1962).

Tuffanelli (1968), Nickerson, Williams, Boxmeyer, and Quie (1970), and Ryan, Parker, and Williams (1972) have reported significant levels of RF activity in heroin addicts. Typically, individuals who are addicted to heroin repeatedly inject themselves with heroin which may also contain other foreign substances. It is a plausible view that heroin or its adulterants are antigenic, or may become antigenic by forming complexes with endogenous protein. Therefore, one might expect in many of these individuals production of antibodies to these antigens. Resultant antigen-antibody complexes could in turn serve as the stimulus for RF production.

An alternative possibility is that RF in heroin addicts is in some way related to the liver dysfunction commonly seen in such individuals. Correlation of RF activity and liver disease has been frequently reported (Bartfeld, 1969).

The purpose of the present study was to follow the course of RF in heroin-dependent persons on methadone maintenance to obtain additional information regarding the pathogenic mechanism of RF production.

\section{Materials and methods}

Patients in this study were members in the Methadone Maintenance Treattment Program at The Mount Sinai Hospital (Stimmel, Bernstein, and Tobias, 1972). Individuals exhibiting clinical or symptomatic evidence of rheumatoid arthritis or connective tissue disease were excluded. As part of the intake examination the slide latex test (RA-Hyland), the tube latex-fixation test (LFT) (Singer and Plotz, 1956), and the tanned sheep cell agglutination test for RF (Oreskes and Plotz, 1965) were performed on all patients. Patients exhibiting +1 on the slide test and a titre of $1: 20$ or greater in the tube test were considered positive for RF. On certain randomly selected RF positive patients, the sensitized sheep cell agglutination tests (Rose, Ragan, Pearce, and Lipman, 1948) were also performed. Both tests employing sheep cells were done on sera previously adsorbed with washed packed sheep red cells. These patients were also tested for antinuclear antibodies with an immunofluorescence procedure using calf thymus smears, and antithyroglobulin antibodies using a commercial test kit (Hyland ATA kit).

The following chemical determinations were performed by standard methods on serum samples from all subjects in the study: protein electrophoresis, glutamic-pyruvic transaminase (GOT), glutamic-oxaloacetic transaminase (GPT), alkaline phosphatase (AP), bilirubin, and the VDRL test for syphilis. Hyperglobulinaemia was defined as a $\beta$ plus $\gamma$ globulin level $>2.5 \mathrm{~g} . / 100 \mathrm{ml}$. Abnormal liver function was presumed if any of the following was obtained: GOT > 50 m.i.U, GPT > 50 m.i.U, AP > 90 m.i.U, or bilirubin $>1.5 \mathrm{mg}$./100 ml. Repeat sera of persons with a reactive VDRL test were tested with the fluorescent treponema antibody absorption technique (FTA-ABS). A biological false positive reaction (BFP) was defined as a positive VDRL associated with a negative FTA-ABS.

All patients were monitored twice a week by thin-layer chromatography of urine to determine the presence of morphine, barbiturates, amphetamines, quinine, and methadone. Patients whose urine was positive for any of these drugs other than methadone were excluded from 
the study. Latex-fixation and liver function tests were repeated after about 1 year on the patients remaining in the study.

\section{Results}

Measurement of RF activity in 163 heroin addicts upon their entrance into a methadone maintenance treatment program revealed a frequency of positive tests of 29 per cent., latex titres ranging from $1: 20$ to $1: 2,560$ (median $1: 160$ ). Using the tanned sheep cell test (TSC) for RF, an even higher positive frequency of 39 per cent. was observed. However, the range and median of titre values were identical to those obtained with the LFT. Examination of the total group of addicts showed that 76 per cent. were hyperglobulinaemic, 49 per cent. showed abnormal liver function tests, and 23 per cent. showed biological false positive (BFP) tests for syphilis. When these data were divided between RF positive and RF negative addicts, there was no significant difference in the frequency of hyperglobulinaemia, elevated liver function tests, or BFP tests between the two groups. These data are summarized in Table $I$.

Table I Initial tests on heroin addicts entering a methadone maintenance treatment program

Symptoms

\begin{tabular}{|c|c|c|}
\hline & \\
\hline & Positive & Negative \\
\hline & $47 / 163(29 \%)$ & $116 / 163 .(71 \%)$ \\
\hline $\begin{array}{l}\text { Abnormal liver function } \\
\text { Hyperglobulinaemia } \\
\text { False positive serological } \\
\text { reaction }\end{array}$ & $\begin{array}{l}23 / 47(49 \%) \\
38 / 47(81 \%) \\
10 / 47(21 \%)\end{array}$ & $\begin{array}{l}57 / 116(49 \%) \\
86 / 116(74 \%) \\
28 / 116(24 \%)\end{array}$ \\
\hline
\end{tabular}

* When the same panel was tested with the more sensitive tanned sheep cell test, 64 (39 per cent.) were positive.

Of the original test group, 143 were re-tested for RF activity with the LFT after 1 year on methadone maintenance. These patients remained free of heroin during this time as judged by thin-layer chromatography of urine. Of the re-test group, 32 had been initially positive for RF and eleven were still positive after 1 year, the other 21 having converted to negative. In the group that converted there was no significant change in the frequency of abnormal liver function tests. Conversion was unrelated to the original RF titre. During this period seven of 111 (6 per cent.) initially negative converted to positive. These data are summarized in Table II.

Twenty patients who were positive for RF were tested for thyroglobulin and antinuclear antibodies. In no instance was either of these antibodies found. This group was also tested with the sensitized sheep cell test which measures RF that is reactive with
Table II Follow-up results on 143 patients after 1 year in methadone maintenance treatment program

\begin{tabular}{|c|c|c|}
\hline Rheumatoid factor (LFT) & Positive & Negative \\
\hline Initial test & 32 & 111 \\
\hline $\begin{array}{l}\text { After } 1 \text { year } \\
\text { Number converting }\end{array}$ & 11 & 104 \\
\hline $\begin{array}{l}\text { Positive to negative } \\
\text { Negative to positive }\end{array}$ & $21^{*}$ & 7 \\
\hline
\end{tabular}

* Abnormal liver function: initially (62 per cent.); after 1 year (64 per cent.).

rabbit gamma globulin, and seventeen ( 85 per cent.) were positive; the titres ranged from $1: 40$ to $1: 640$ (median 1:80). Finally, these twenty sera were treated with $0 \cdot 1 \mathrm{M}$ mercaptoethanol. In every case this treatment abolished all RF activity.

\section{Comment}

The results of this study show that a high proportion of heroin addicts in a methadone maintenance treatment program had significant titres of serum rheumatoid factors at the time of entry into the pro gram. The actual frequency of positive tests was 29 per cent. with the latex-fixation test and 39 per cent. with the more sensitive tanned sheep cell test. Frequency of RF positive tests for an unselected normal control group previously studied in this laboratory were 4 and 8 per cent. respectively, for these two procedures (Oreskes and Siltzbach, 1968).

Tuffanelli (1968) noted the presence of RF activity in narcotic addicts. Nickerson and others (1970) reported positive latex-fixation tests in 9 of 25 (32 per cent.) heroin addicts. In a later series of addicts, Ryan and others (1972) reported a 44 per cent. frequency of RF positive tests. The results of the present study are in reasonable agreement with these earlier reports.

In the present series, the presence of RF activity did not correlate with abnormal liver function or with infection as judged by standard liver function tests or measurement of globulin levels. Furthermore, a search for other autoantibodies, such as antinuclear antibody or antithyroglobulin antibody, failed to demonstrate any evidence of an 'autoimmune state'.

Ryan and others (1972) have shown that serum immunoglobulin G (IgG) derived from heroin addicts specifically bind morphine (diacetyl heroin), and suggested that an immune response to morphine occurs in some patients addicted to heroin or its analogs. These investigators also showed that normal IgG could also bind morphine, but more weakly. These observations suggest that heroin may bind nonspecifically to serum proteins, and that heroin in this 
form could behave as a hapten. With repeated injections of heroin, the host is subjected to chronic antigenic stimulation. In the present study, after 1 year during which the patients no longer 'immunized' themselves (that is, they stopped injecting heroin), 21 of 32 (66 per cent.) who were originally RF positive converted to negative.

In the experimental animal repeated injection of a foreign protein results in the production of specific antibody to the injected antigen followed by the production of rheumatoid-like factors (Abruzzo and Christian, 1961; Aho and Wager, 1961). When the injection of foreign protein is halted, the titre of the rheumatoid-like factors soon decreases markedly. Thus the disappearance of RF in the heroin addict may be related to the cessation of the immune stimulus, that is, the cessation of heroin injections.

The RF present in patients with conditions other than rheumatoid arthritis differs in respect to antigenic specificity, quantity, and constancy from RF in patients with rheumatoid arthritis. In rheumatoid arthritis, RF reacts with both rabbit and human IgG; it is present in high titre (the mean titre of RF among patients with definite rheumatoid arthritis in our laboratory is $1: 2,560$ ), and remains constant independent of the course of the disease, that is, during periods of remission or exacerbation. In diseases other than rheumatoid arthritis, RF tends to react only with human IgG: RF is present in lower titre (mean $=1: 160$ ) (Oreskes and Siltzbach, 1968s, and tends to disappear when the underlying illness is cured or is in remission. In respect to two of these three features, RF in the heroin group behaves like RF found in diseases other than rheumatoid arthritis. Only in the high number of positive tests obtained with the sensitized sheep cell procedure (reactivity with rabbit IgG) does the RF of heroin addicts resemble the RF of rheumatoid arthritis. But here, too, titres were lower than those usually encountered in rheumatoid arthritis.

In seven patients whose sera were negative on initial testing, the reaction became positive a year later, presumably because of transient virus infections. Transient production of rheumatoid factor under these circumstances has been described (Bartfeld, 1969). The failure to find a higher incidence of RF in these addicts after 1 year of oral methadone treatment suggests that this regimen does not stimulate RF production.

Of interest is the recent report of Cushman and Grieco (1973), who demonstrated that 69 per cent. of 109 heroin addicts seeking methadone maintenance exhibited high levels of serum immunoglobulin $\mathbf{M}$ (IgM) which did not correlate with manifest liver disease or elevated GOT or AP levels. A prospective study of 21 patients showed a drop in mean IgM levels during methadone maintenance. It may be noted that, in the present study, treatment with mercaptoethanol abolished all RF activity, suggesting that in our group the RF was of the IgM variety.

The presence of other serological abnormalities in heroin users, such as biological false positive reactions, hypergammaglobulinaemia, and febrile agglutinins, is well known, and suggests a protean disorder in the immunoproliferative system (Boak, Carpenter, and Miller, 1961; Cherubin and Millian, 1968; Vogel, Cherubin, and Millian, 1970; Nickerson and others, 1970). Alteration in cellular immune function, reflected by impaired responsiveness in lymphocyte culture to phytohaemagglutinin, has also been reported (Brown, Stimmel, Taub, and Kochwa, 1970).

Judging from our data, the presence of RF in the sera of drug addicts is best explained on the basis of chronic antigenic stimulation. This process is comparable to production of RF in diabetic patients on insulin (Oreskes and Spiera, 1973), and in individuals subjected to repeated blood transfusions (Vierucci, 1965). The sequence of events appears to be: primary antigenic stimulation, primary antibody response, formation of antigen-antibody complexes, and finally RF production directed against altered IgG in the original antigen-antibody complex. It would appear that this process occurs in many individuals with a wide variety of diseases, thus making rheumatoid factor production a very widespread immunological phenomenon.

\section{Summary}

In a prospective study of heroin users upon entry into a methadone maintenance treatment program, 47 of 163 (29 per cent.) exhibited significant titres of rheumatoid factor activity with the latex-fixation test, which was unrelated to the presence of liver dysfunction, hyperglobulinaemia, or biological false positive serological reaction. After 1 year of oral methadone maintenance in the absence of continued heroin injection, 21 of 32 addicts initially positive for rheumatoid factor became negative. These results are consistent with previous clinical and animal studies, and suggest that rheumatoid factor production is associated in these individuals with their previous history of heroin injection. Cessation of heroin injection appears to remove the stimulus for rheumatoid factor production.

The technical assistance of Mrs. Evelyn Eason is gratefully acknowledged.

This work was aided by the National Institutes of Health Grant RR-71, and by grants from the New York Chapter of the Arthritis Foundation. The Methadone Maintenance Treatment Program is funded in part by the New York State Narcotic Addiction Control Commission. 


\section{References}

Abruzzo, J. L., ANd Christian, C. L. (1961) J. exp. Med., 114, 791 (The induction of a rheumatoid factor-like substance in rabbits)

Aho, K., Konttinen, A., Rajasalmi, M., And Wager, O. (1962) Acta path. microbiol. scand., 56, 478 (Transient appearance of the rheumatoid factor in connection with prophylactic vaccinations)

- AND WAGER, O. (1961) Ann. Med. exp. Biol. fenn., 39, 79 (Production of anti-antibodies in rabbits)

BARTFELD, H. (1960) Ann. intern. Med., 52, 1059 (Incidence and significance of seropositive tests for rheumatoid factor in nonrheumatoid diseases) (1969) Ann. N.Y. Acad. Sci., 168, 30 (Distribution of rheumatoid factor activity in nonrheumatoid states)

Boak, R. A., Carpenter, C. M., and Miller, J. N. (1961) J. Amer. med. Ass., 175, 326 (Biologic false positive reactions for syphilis among narcotic addicts)

Brown, S. M., Stimmel, B., TaUb, R. N., AND Kochwa, S. (1970) 'XII Congress, International Society of Hematology, Munich' (Immunological dysfunction in heroin addicts)

Cherubin, C. E., ANd Millian, S. J. (1968) Ann. intern. Med., 69, 739 (Serologic investigations in narcotic addicts. I. Syphilis, lymphogranuloma venereum, herpes simplex, and $Q$ fever).

Cushman, P., AND Grieco, M. H. (1973) Amer.J. Med., 54, 320 (Hyperimmunoglobulinemia associated with narcotic addiction. Effects of methadone maintenance treatment)

Nickerson, D. S., Williams, R. C. JR., Boxmeyer, M., AND Quie, P. G. (1970) Ann. intern. Med., 72, 671 (Increased opsonic capacity of serum in chronic heroin addiction)

ORESKES, I., AND PloTz, C. M. (1965) J. Immunol., 94, 567 (Autoinhibition of rheumatoid factor reactivity demonstrated by a block hemagglutination procedure)

- AND SiltzBACH, L. E. (1968) Amer. J. Med., 44, 60 (Changes in rheumatoid factor activity during the course of sarcoidosis)

- AND SPIERA, H. (1966) J. Amer. med. Ass., 198, 384 (Use of fingertip blood in detection of rheumatoid factor) (1967) Excerpta Medica Int. Congr. Series No. 143, p. 1 (Rheumatoid factor in rheumatoid arthritis and other diseases)

_ (1973) Ann. rheum. Dis., 32, 431 (Diabetes and rheumatoid factor)

Rose, H. M., Ragan, C., Pearce, E., And Lipman, M. O. (1948) Proc. Soc. exp. Biol. (N.Y.), 68, 1 (Differential agglutination of normal and sensitized sheep erythrocytes by sera of patients with rheumatoid arthritis)

Ryan, J. J., Parker, C. W., AND Williams, R. C., JR. (1972) J. Lab. clin. Med., 80, 155 ( $\gamma$ Globulin binding of morphine in heroin addicts)

Singer, J. M., AND Plotz, C. M. (1956) Amer. J. Med., 21, 888 (The latex fixation test. I. Application to the serological diagnosis of rheumatoid arthritis)

- - - Peralta, F. M., ANd Lyons, H. D. (1962) Ann. intern. Med., 56, 545 (Presence of antigamma globulin factors in sera of patients with active pulmonary tuberculosis)

Stimmel, B., Bernstein, M., AND Tobias, H. (1972) N.Y. St.J. Med., 72, 2673 (Methadone maintenance program. A voluntary hospital's experience)

Tuffanelli, D. L. (1968) Arch. Derm., 98, 606 (False positive reactions for syphilis)

VIERUCCI, A. (1965) Vox Sang., 10, 82 (GM groups and anti-GM antibodies in children with Cooley's anaemia)

Vogel, H., Cherubin, C. E., ANd Millian, S. J. (1970) Amer. J. clin. Path., 53, 932 (Febrile agglutinin in narcotic addicts)

Williams, R. C., JR., AND Kunkel, H. G. (1962) J. clin. Invest., 41, 666 (Rheumatoid factor, complement, and conglutinin aberrations in patients with subacute bacterial endocarditis) 